\title{
PILOTSKI PROJEKT: VOJAŠNIČNI KLUBI V SLOVENSKI VOJSKI IN POT NAPREJ
}

\author{
PILOT PROJECT: MILITARY CLUBS IN THE \\ SLOVENIAN ARMED FORCES AND A WAY AHEAD
}

Povzetek Prispevek obravnava vzpostavitev in delovanje vojašničnih klubov v Slovenski vojski. Pripadnik je najpomembnejši dejavnik v delovanju Slovenske vojske. S profesionalizacijo Slovenske vojske je celostna skrb za pripadnike postala pomemben dejavnik. Namen prispevka je predstaviti trenutno stanje in oblikovanje dejavnosti ter programov za izboljšanje celostne skrbi za pripadnike Slovenske vojske. Model delovanja vojašničnih klubov še ni v celoti izoblikovan in uveljavljen v praksi. Dostopni so nekateri modeli, ki jih uporabljajo druge vojske v Natu in zunaj.

Rezultat dosedanjega dela pilotskega projekta je odprtje dveh vojašničnih klubov v vojaškem objektu Kadetnica v Mariboru in Vojašnici Jerneja Molana v Cerkljah ob Krki. Pri tem je vzpostavitev vojašničnih klubov dosegla naslednje cilje: izvajanje dejavnosti z lastnim kadrom, cenejše storitve za pripadnike SV in skozi delovanje vojašničnih klubov zagotavljanje upravičenosti delovanja projekta. Skozi testno obdobje pilotskega projekta smo dokazali, da je delovanje vojašničnih klubov v Slovenski vojski upravičeno. Na podlagi delovanja vojašničnih klubov bi lahko vzorec delovanja gostinske dejavnosti prenesli tudi na druge dejavnosti. S širitvijo števila dejavnosti bi lahko podprli večji nabor programov za dvig kakovosti celostne skrbi pripadnikov Slovenske vojske.

Ključne besede

Abstract

\section{Vojašnični klub, pilotski projekt, celostna skrb, gostinska dejavnost, prodaja blaga.}

The article deals with the establishment and activities of military clubs in the Slovenian Armed Forces (SAF). Personnel and individuals are the most important factor in SAF activities. With the professionalization of the SAF, the care for its servicemembers and their welfare became all the more important. The intent of the text is to present the current state of affairs and the development of activities 
and programmes to improve the welfare of SAF members. The actual model of the operation of military clubs is still not entirely designed and applied; however, some welfare models of foreign NATO and non-NATO armed forces' are available.

As a result of the pilot project, two military clubs have opened, namely one in the "Kadetnica" facility in Maribor and one in "Jernej Molan" barracks at Cerklje ob Krki. In this respect, the objectives have been achieved, such as the engagement of the SAF's own personnel, provision of low-priced products for SAF members, and justification of the project through the actual functioning of the clubs. The pilot testing period has thus proven the relevance of the idea. On the basis of club activities, the canteen services could be expanded to other areas as well, which would provide for a variety of programmes to raise the quality of SAF members' welfare.

Key words Military club, pilot project, SAF personnel welfare, canteen services, sale of goods.

Uvod V procesu razvoja Slovenske vojske (v nadaljevanju: SV) smo razvijali različna področja. Eno izmed področij, ki smo jih v preteklosti v SV že večkrat poskušali razviti, so tudi vojašnični klubi (v nadaljevanju: VK). Projekt celostne skrbi za pripadnike SV in njihove družinske člane (CSP SV) se je začelo maja 2002. Oblikovalo se je šest podprojektov CSP, ki so se pred koncem leta 2002 prenesli v projekt »profesionalizacija SV, poklicna vojska, dopolnjena z rezervo (PROVOJ)«, z nalogo nadaljnjega razvoja programov CSP. Projekt se je začel izvajati leta 2003, skladno z zagonskim elaboratom.

Leta 2007 je bil sprejet Zakon o Slovenski vojski, s katerim so bile določene normativne podlage za delovanje VK oziroma centrov za celostno skrb. O delovanju VK se je razmišljalo tudi ob sprejetju Pravil službe SV leta 2009.

V ta namen bi na GŠSV ustanovili oddelek CSP, ki bi skrbel za konceptualni razvoj posameznih programov. Te bi ponujali prek VK v okviru vojašnic ali v centrih za CSP (Pokljuka, Bukovje, Debeli rtič itn.). Centre za CSP bi morali ustanoviti, namensko opremiti in formacijsko popolniti (povzeto po Štemberger, 2007, str. 17).

Leta 2011 je bila v Oddelku za celostno skrb za pripadnike SV na GŠSV (v nadaljevanju OCSP/GŠSV) sprejeta odločitev o ponovni oživitvi vzpostavitve VK v SV. Opravljeni so bili številni pogovori s takratnimi poveljniki posameznih vojašnic oziroma njihovimi najožjimi sodelavci. Cilj pogovorov je bil pridobiti vpogled v dejansko stanje na tem področju, v ideje o smiselnih oblikah organiziranja VK ter v realne možnosti za vzpostavitev klubskih dejavnosti. Izveden je bil pregled normativnih aktov, ki podpirajo delovanje VK. V enotah in poveljstvih SV je bila narejena anketa na temo vojašnični klubi v SV. Na podlagi opravljenih pogovorov, pregleda normativnih dokumentov, analize rezultatov, pridobljenih z anketo, ter v želji izboljšati ponudbe v okviru celostne skrbi za pripadnike SV in njihove družinske člane je bila dana pobuda o ustanovitvi VK. Maja 2015 so na GŠSV izdali ukaz za izvedbo pilotskega projekta vzpostavitve 
VK. Oblikovana je bila delovna skupina pod vodstvom majorja Antona Kandutija, ki naj bi pripravila pogoje za izvedbo in delovanje VK v vojašnicah SV leta 2015 (Ukaz GŠSV, št. 812-2/2015-61, z dne 4. 5. 2015).

\section{NAMEN DELOVANJA VOJAŠNIČNIH KLUBOV}

Namen pilotskega projekta je bil vzpostaviti dva VK na lokacijah VOK Maribor in VJM Cerklje ob Krki. Maja 2015, ob dnevu odprtih vrat enot, je delovna skupina na omenjenih lokacijah odprla dva VK in začela izvajati gostinske dejavnosti. Pri vzpostavitvi delovanja VK je delovna skupina določila tri glavne cilje:

- izboljšati ekonomski standard vseh pripadnikov SV v MO RS, ki uporabljajo dejavnosti VK;

- reševati status pripadnikom SV, ki ne morejo več opravljati vojaške dolžnosti (zdravstvene omejitve, starostna omejitev in zakonske omejitve);

- doseči ekonomski učinek in tako upravičiti rentabilnost projekta.

$\mathrm{Z}$ delovanjem VK se je prispevalo $\mathrm{k}$ dvigu zadovoljstva med pripadniki $\mathrm{SV}$ in njihovimi družinskimi člani. VK bi lahko postali stičišče medgeneracijskega druženja in vez do drugih civilnih organizacij, zvez in društev.

\subsection{Normativni akti in predpisi, ki urejajo področje za delovanje vojašničnih klubov}

Za uspešno izvajanje programa CSP je potrebna ustrezna pravna podlaga. Normativno ureditev CSP v SV urejajo zakoni in interni akti, ki so sprejeti v okviru SV. CSP v ZObr ni opredeljena kot celota, vendar so že opredeljena določena področja, kot so verska in duhovna oskrba ter določene pravice iz zdravstvenega zavarovanja nujne medicinske pomoči (povzeto po Tepeh, str. 38).

Z uveljavitvijo Zakona o službi v Slovenski vojski (ZSSloV) v SV se je postavila normativna podlaga za delovanje vojašničnih klubov ${ }^{1}$. S Pravili službe v Slovenski vojski so se določili načini delovanja $\mathrm{VK}^{2}$. Z Navodilom o lastni dejavnosti se na Ministrstvu za obrambo in v organih v sestavi dodajo vrsta lastne dejavnosti, način

\footnotetext{
Zakon o službi v Slovenski vojski (ZSSloV), 85. člen, Uradni list RS št. 68/2007 z dne 30. 7. 2007. »V vojašnicah se določi klubski prostor, ki lahko obsega tudi knjižnico, medioteko in druge prostore in je namenjen srečevanju pripadnikov, njihovih družinskih članov in priložnostnim prireditvam. Poslovanje klubov se ureja s Pravili službe v SV. Za izvajanje klubskih, športnih, rekreativnih, muzejskih in drugih dejavnosti pripadnikov in njihovih družinskih članov se lahko z ustreznimi pogodbami, skupaj s častniško ali veteransko organizacijo, organizirajo tudi centri za celostno skrb."

2 Pravila službe v Slovenski vojski (Uradni list RS št. 84/2009 z dne 27. 10. 2009, 184. in 185. člen). »V vojašnicah se določi klubski prostor, ki lahko obsega knjižnico, medioteko, spominsko sobo, muzejske in druge zbirke ter druge prostore, ki so namenjeni druženju pripadnikov, njihovih družinskih članov in priložnostnim prireditvam. Klubske prostore lahko uporabljajo vsi pripadniki Slovenske vojske, upokojeni pripadniki, družinski člani ter druge osebe v skladu s hišnim redom ali po predhodni odobritvi upravnika kluba. Klubski prostori, igrišča in prostori za različne druge oblike celostne skrbi za pripadnike in družinske člane se lahko uporabljajo na način in v času, da ne motijo redne dejavnosti poveljstev, enot in zavodov v vojašnici. Delo kluba vodi upravnik kluba. Če se v vojašnici organizira prireditev odprtega značaja, mora upravnik kluba pridobiti soglasje poveljnika vojašnice. Poveljnik vojašnice v hišnem redu predpiše obratovalni čas kluba ter ostale pogoje za izvajanje celostne skrbi.«
} 
financiranja lastne dejavnosti, evidence in oblikovanje cen proizvodov ter storitev iz naslova lastne dejavnosti (dok. MO RS št. 017-04-7/2003-4 z dne 24. 2. 2003).

Na podlagi normativnih aktov si je Slovenska vojska predpisala akte poveljevanja (vojaška doktrina ${ }^{3}$, direktiva ${ }^{4}$ in standardni operativni postopek (SOP)), v katerih je podrobno opredelila ureditev tega področja. SOP o načrtovanju programov celostne skrbi v enotah in poveljstvih SV in poročanje o realizaciji določa organizacijo načrtovanja razvoja in izvedbe programov CSP ter njihovo prostorsko zagotovitev, kamor spada tudi klubska dejavnost v SV (SOP št. 05-0007, GŠSV št. 804-337/2009$1 \mathrm{z}$ dne 10. 9. 2009).

\subsection{Rezultati izvedene ankete Vojašnični klubi v SV}

Leta 2013 je bila med pripadniki SV izvedena anketa. V anketi je sodelovalo 890 pripadnikov SV, kar pomeni 11,7 odstotka vseh zaposlenih v Slovenski vojski. Od 890 oddanih anket je bilo 829 anket veljavnih (99,2 odstotka) in 61 neveljavnih (0,8 odstotka).

\section{Empirična analiza ankete Vojašnični klubi v SV}

V OCSP/GŠSV je bila izvedena obdelava anketnih vprašalnikov na tematiko Vojašnični klubi v SV.
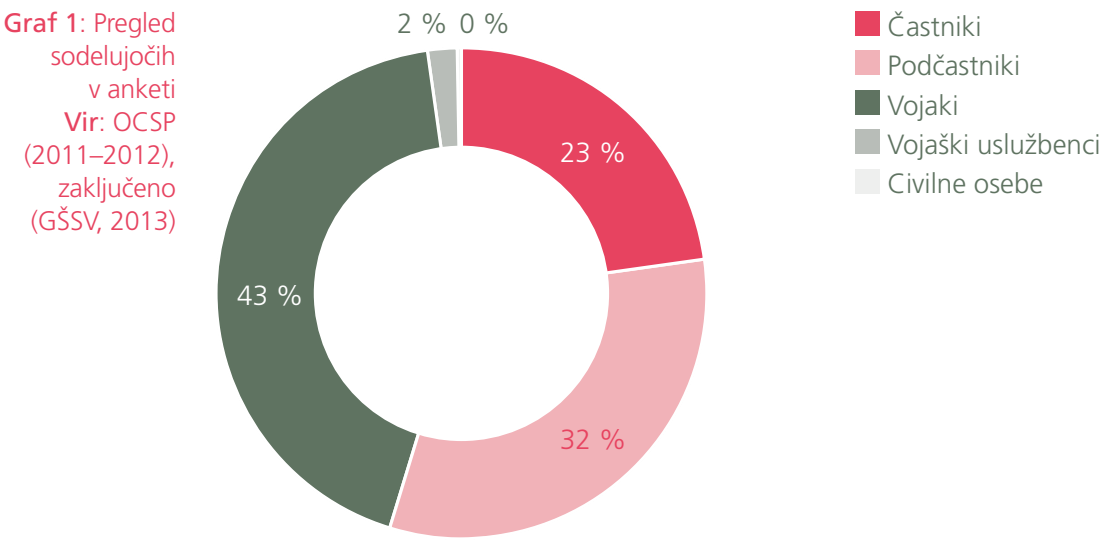

3 Vojaška doktrina (PDRIU, Vojaško doktrino je sprejela vlada Republike Slovenije na svoji 76. seji, 1. junija 2006). »Celostna skrb za pripadnike Slovenske vojske je dejavnost, ki je namenjena zagotovitvi dobrega počutja in dobrobiti pripadnikov Slovenskem vojske in njihovih družinskih članov. Obsega skrb za dušeno zdravje in osebnostno rast, duhovno oskrbo, zdravstveno oskrbo, zagotovitev bivalnih možnosti, podporo družinam, varnost pri delu, športno in kulturno udejstvovanje, interesno dejavnost in stanovsko organiziranost."

4 Direktiva za razvoj in izvajanje celostne skrbi za pripadnike SV, dok. GŠSV št. 804-338/2009-1 z dne 16. 9. 2009. „V organizacijsko shemo delovanja CSP vključite tudi prostorsko ureditev, ki zajema centre za CSP izven vojašnic in prostore v vojašnicah, kot so klubi, spominske sobe ..." 
Pri izvedbi ankete so bile zajete vse kategorije zaposlenih v SV. Pri tem je bil največji poudarek na ciljni populaciji vojakov.

Graf 2:

Smiselnost vzpostavitve VK

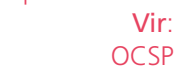

(2011-2012),

zaključeno

(GŠSV, 2013)

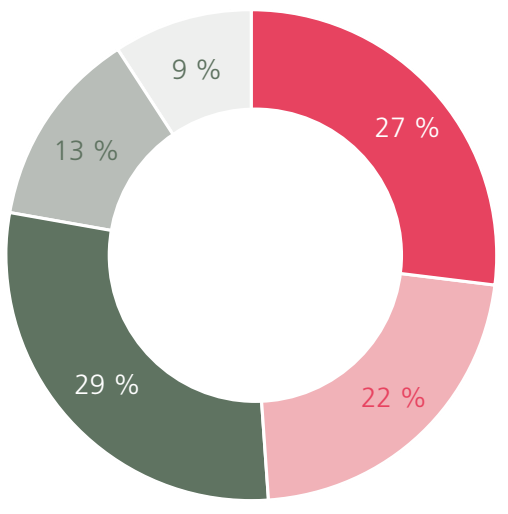

"Ali se vam zdi vzpostavitev VK smiselna in koristna za vas in vaše družinske člane? « (818)

Zelo podpiram

Podpiram z odobravanjem

Podpiram

Delno podpiram

Ne podpiram

$\mathrm{Na}$ vprašanje o smiselnosti ustanovitve je 91 odstotkov vprašanih odgovorilo, da zamisel o ustanovitvi VK podpirajo, 9 odstotkov pripadnikov pa zamisli o ustanovitvi VK ne podpira.

Graf 3: Predlogi različnih modelov VK Vir: OCSP

(2011-2012), zaključeno (GŠSV, 2013)
Podpira Delno podpira Ne podpira

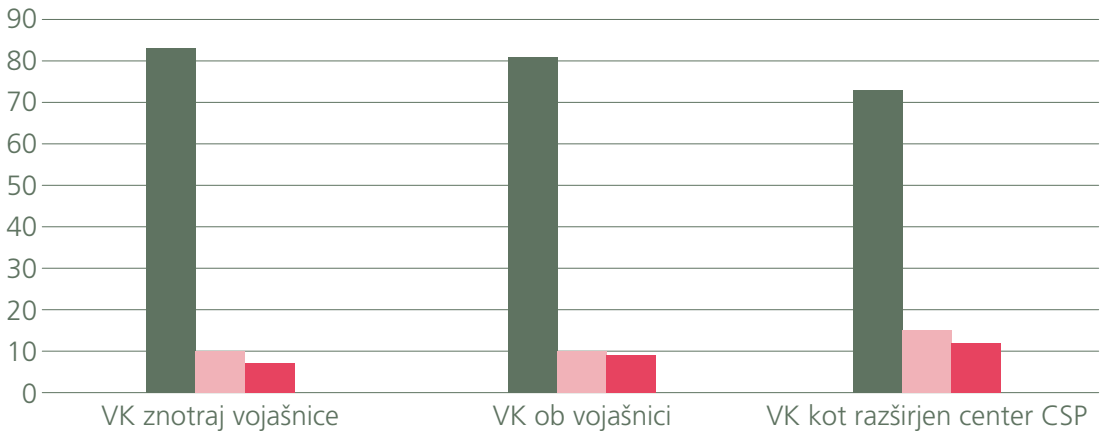

83

10

81

10

9

Pri oceni različnih modelov VK so bili vsi trije modeli ocenjeni kot sprejemljivi, pri čemer je bila največja podpora za model, pri katerem bi VK deloval znotraj vojaških objektov. 
Graf 4: Ali $\vee$ VK vidite smiselnost druženja med generacijami?

$$
\text { Vir: }
$$

(2011-2012),

zaključeno

(GŠSV, 2013)

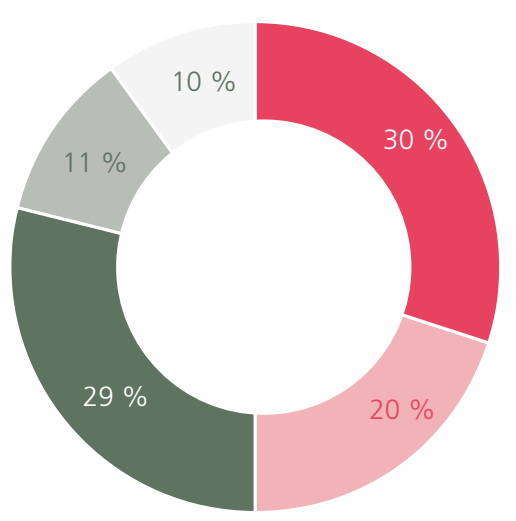

»Ali so VK smiselni kot medgeneracijsko središče» (784)

Zelo podpiram

Podpiram z odobravanjem

Podpiram

Delno podpiram

Ne podpiram

Pri ocenjevanju smiselnosti VK kot medgeneracijskega središča je 90 odstotkov anketiranih pozitivno podprlo tako obliko delovanja VK.

Graf 5: Pregled programov $\vee$ VK

$$
\begin{array}{r}
\text { Vir: } \\
\text { OCSP }
\end{array}
$$

(2011-2012),

zaključeno (GŠSV, 2013)

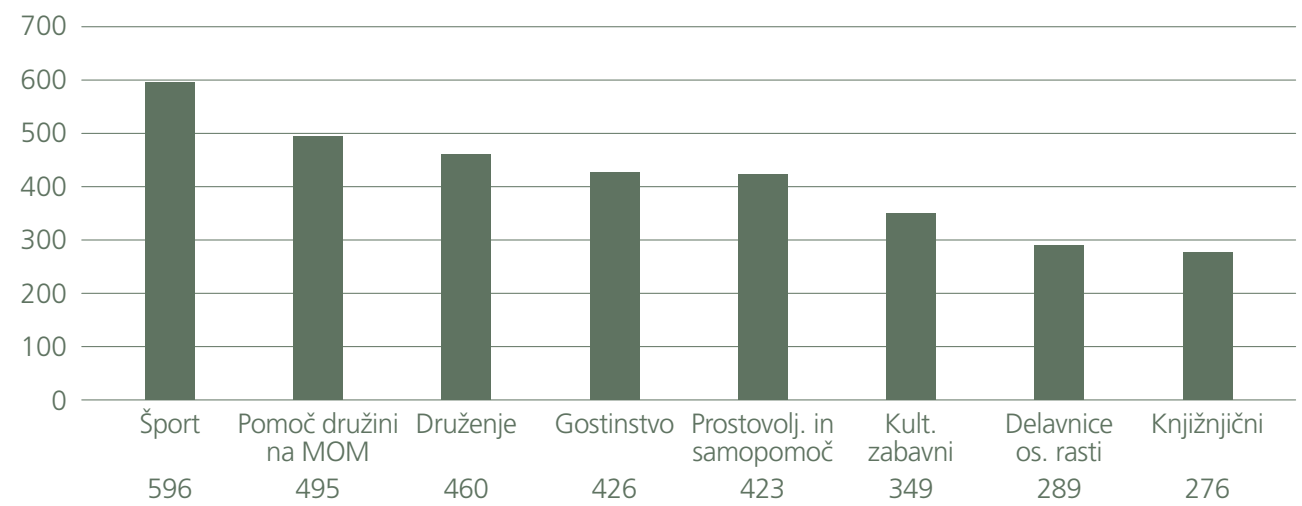

Pri pregledu programov, ki bi jih ponujali VK, so anketirani podprli vse ponujene programe. Posebno naklonjenost so namenili športnim aktivnostim, skrbi družinskim članom pripadnikov v času MOM in druženju ter gostinski dejavnosti. 
Graf 6:

Na katerih področjih želite sodelovati $\vee$ VK?

Vir: OCSP

(2011-2012),

zaključeno

(GŠSV, 2013)

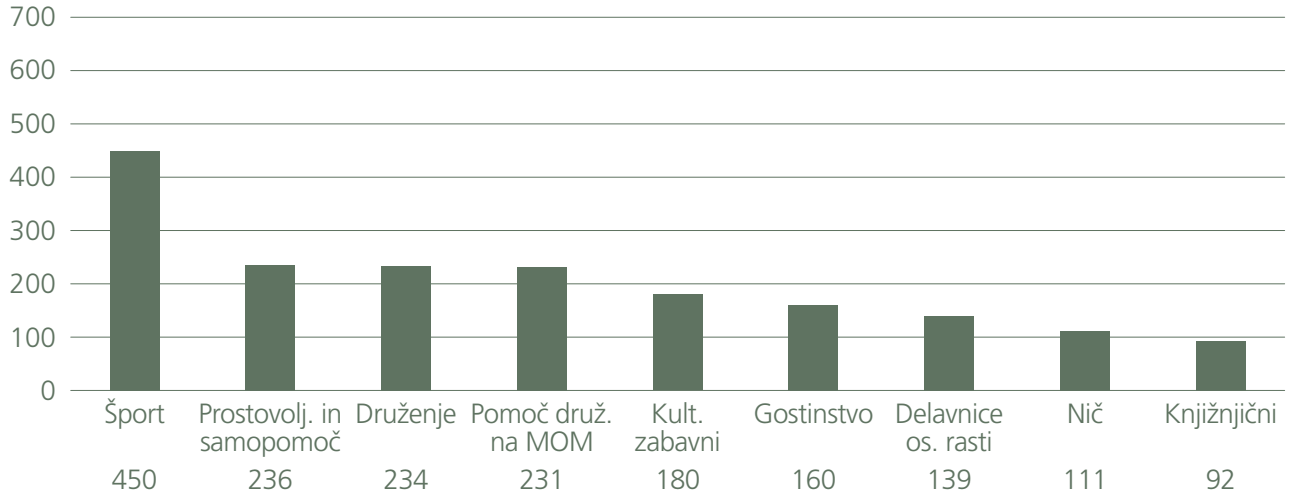

Enako so anketirani ocenili tudi področja, na katerih bi bili pripravljeni aktivno sodelovati.
Graf 7: Ali vas

zanima delo v VK po končani vojaški karieri

(vojak po 45. letu dopolnjene starosti)? Vir: OCSP

(2011-2012).

zaključeno

(GŠSV, 2013)

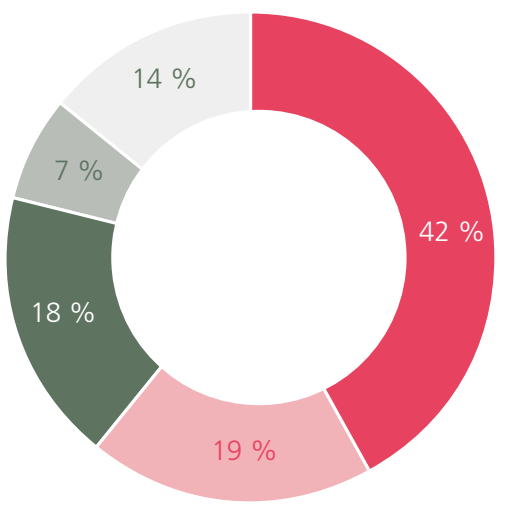

»Ali bi bili po 45. letu starosti pripravljeni delati v vVK (vojaki)« (509)

Zelo podpiram

Podpiram z odobravanjem

Podpiram

Delno podpiram

Ne podpiram

86 odstotkov anketiranih pripadnikov (vojakov) bi želelo svojo poklicno kariero nadaljevati znotraj sistema SV. V VK vidijo eno izmed možnosti zaposlitve. 
Graf 8: Vpliv različnih dejavnikov na uporabljanje storitev VK Vir: OCSP

(2011-2012), zaključeno (GŠSV, 2013)

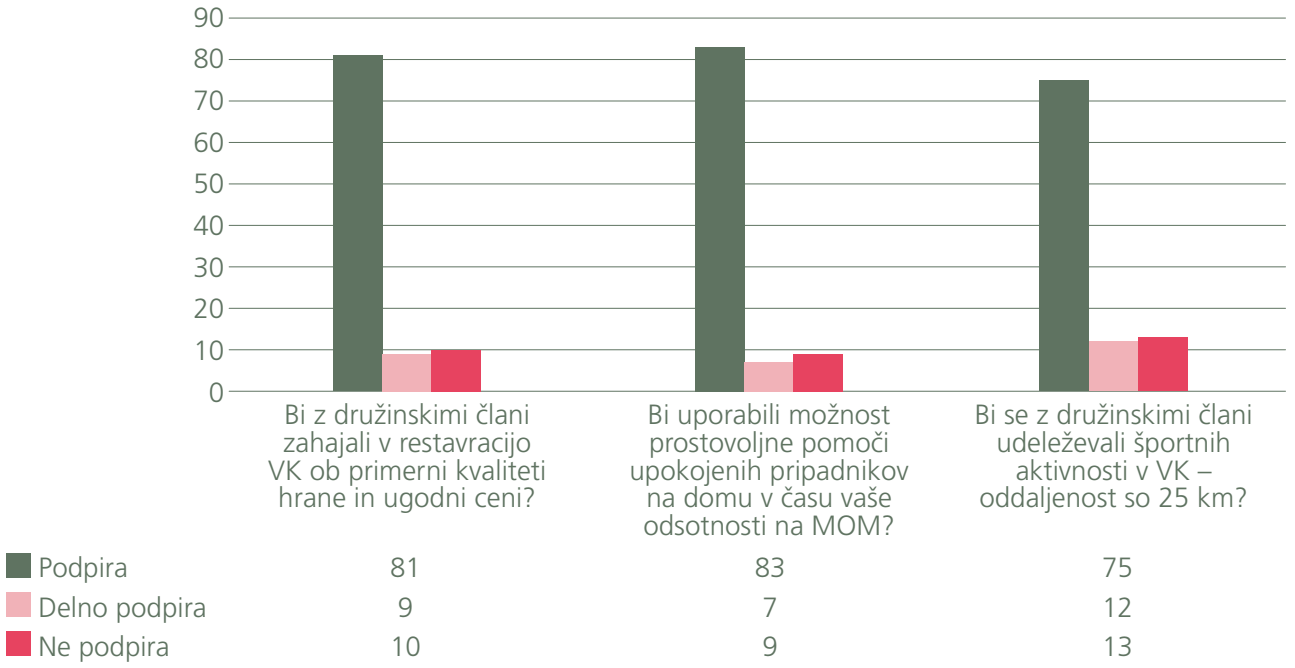

Vsi anketirani so podprli možnosti, ki bi jih ponudili znotraj delovanja VK za pripadnike in njihove družinske člane.

\subsubsection{Izbor kadra}

Za izvajanje koncepta CSP, ki prinaša nove in številčnejše programe, pa bo treba doseči, da bodo za opravljanje teh nalog določena delovna mesta vključena v okvir formacij posameznih enot. V okviru vojašnice je treba pripraviti predlog oblikovanja stalnega jedra centra CSP, ki bi organizirano in sistematično skrbel za pripravo in izvedbo vseh načrtovanih programov ter usklajeval potrebne aktivnosti med enotami v vojašnici ter z neposrednim civilnim okoljem. Na oblikovanje takega centra kaže tudi ugotovitev iz usmerjenega intervjuja, da poveljstva in enote premalo poznajo koncept CSP in možnosti, ki jih ponuja (povzeto po Veselič, str. 81).

Izbor kadra je predviden med pripadniki, ki zaradi zdravstvenih ali starostnih omejitev niso več sposobni opravljati vojaške službe. Odvisen je tudi od dejavnosti in programov, ki se bodo izvajali v VK. Zaradi specifičnosti lokacij ne bo mogoče doseči enega samega modela VK, ki bi bil univerzalen za vse objekte, v katerih bodo delovali VK. Specifičnost lokacij določajo velikost vojašnice, število pripadnikov, ki so nastanjeni v vojašnici, in namembnost vojašnice.

\subsubsection{Status zaposlenih v vojašničnih klubih}

V VK bi lahko delo opravljali pripadniki, ki bi jim prenehalo delovno razmerje v SV brez krivdnih razlogov (npr. vojaki po 45. letu starosti in vojaške osebe z različnimi omejitvami, zaradi katerih niso več sposobni opravljati vojaške službe, oziroma dolžnosti, na katero so razporejeni). Vojaki, ki jim preneha pogodba o zaposlitvi za določen čas zaradi dopolnitve starosti 45 let, bi se lahko razporedili v VK kot CO ali izjemoma VU, odvisno od dejavnosti in programov, ki bi jih v VK izvajali. 


\subsection{Prostorska, materialna in finančna zagotovitev delovanja vojašničnih klubov}

Po ogledu objektov v SV je bilo ugotovljeno, da vojašnice že imajo objekte, v katerih se je že $\mathrm{v}$ prejšnjem sistemu izvajala gostinska dejavnost. V času naborniškega sistema smo večino teh objektov oddali zunanjim izvajalcem, preostalim objektom pa smo spremenili namembnost uporabe. Vojašnice imajo tudi druge prostorske zmogljivosti za izvajanje drugih dejavnosti in programov v VK.

Materialna sredstva za izvajanje določenih dejavnosti so deloma že zagotovljena. Večina vojašnic objekte za opravljanje gostinske dejavnosti že ima, prav tako je v teh objektih oprema za izvajanje gostinskih dejavnosti oziroma je trenutno $\mathrm{v}$ uporabi in najemu pri zunanjih najemnikih teh prostorov. V VOK Maribor imajo že zagotovljen in opremljen prostor za opravljanje trgovinske dejavnosti. Glede na širjenje dejavnosti in programov pa se bodo materialna sredstva $\mathrm{v}$ drugih vojašnicah zagotavljala, kadar bo to potrebno.

Pri vzpostavitvi VK skozi pilotski projekt je DS uporabila model financiranja skozi lastno dejavnost. Na podlagi tega se lahko del finančnih sredstev, pridobljenih z lastno dejavnostjo, uporabi za širitev različnih dejavnosti, s katerimi se lahko podpre različen izbor programov v okviru CSP.

\section{IZVAJANJE PILOTSKEGA PROJEKTA VOJAŠNIČNIH KLUBOV}

DS je za izvedbo pilotskega projekta pri svojem delu sledila nameri, da želijo z vzpostavitvijo VK doseči tako ekonomske kot tudi socialne učinke. Kot prvo želijo izboljšati ekonomski standard vseh pripadnikov SV, ki koristijo dejavnosti VK. Za delovanje VK bomo uporabili lastne kadrovske vire in tako pripomogli k reševanju statusa tistih pripadnikov SV, ki ne morejo več opravljati vojaške dolžnosti zaradi starosti ali zdravstvenih omejitev. Nazadnje pa nameravajo s projektom doseči tudi ekonomski učinek in upravičiti izvajanje projekta.

Pri delovanju VK uporabljajo svojo grafično podobo in slogan VK, ki se glasi: »Tu smo zaradi vas.«

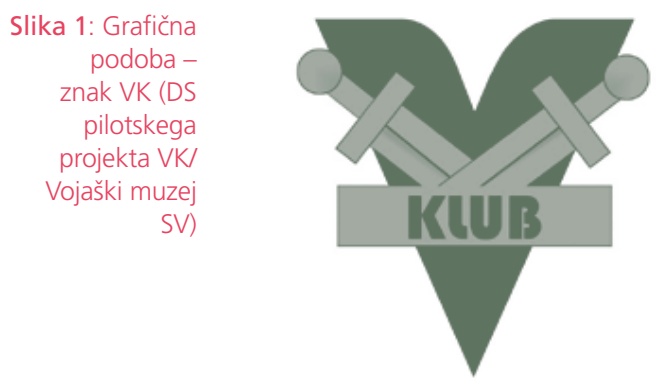




\subsection{Delovanje vojašničnih klubov}

Delovanje VK je mogoče zagotoviti različno, in sicer:

- z zunanjimi pogodbenimi sodelavci,

- z modelom koncesionarjev - partnerstva s stanovskimi organizacijami,

- z modelom lastne dejavnosti.

DS je za delovanje VK uporabila model lastne dejavnosti in pri tem opredelila dva načina delovanja VK.

\section{a. Vojaški klub kot samostojna organizacijska enota}

V primeru organiziranosti VK kot samostojne organizacijske enote bi bilo treba določiti formacijo, po kateri bi se formacijske dolžnosti opravljale v statusu civilne osebe ali izjemoma v statusu vojaškega uslužbenca, seveda ob izpolnjevanju drugih pogojev za opravljanje določene dejavnosti v VK.

VK bi vodil upravnik VK, ki načrtuje, usklajuje delo in vodi aktivnosti VK ob izvajanju storitev v okviru lastne dejavnosti.

Za izvajanje nekaterih aktivnosti zunaj dejavnosti se lahko angažirajo zunanji izvajalci (fizične ali pravne osebe, npr. najem ansambla itn.). Fizične osebe bi lahko delo opravljale po podjemni pogodbi, pravne osebe pa po klasični obligacijski pogodbi o naročilu blaga in storitev.

VK kot samostojna organizacijska enota bi po oceni delovne skupine dosegla najvišje socialne in ekonomske učinke.

\section{b. Vojaški klub, ki ni organiziran kot samostojna organizacijska enota}

Če VK ne deluje kot samostojna organizacijska enota, obstaja možnost, da se v okviru EVOJ sistemizirajo formacijske dolžnosti, ki so namenjene delovanju VK (npr. podčastnik za podporo). V opisu del nalog tega podčastnika so vodenje VK in naloge, ki se na to nanašajo (upravljanje prostora, načrtovanje dela, nabava materiala, finančno poslovanje, načrtovanje, koordinacija in izvedba aktivnosti, koordinacija izvajalcev dejavnosti itn.). Za izvedbo vseh dejavnosti VK je poleg podčastnika za podporo VK treba z aktom vodenja in poveljevanja (ukaz po 98. členu Zobr) začasno razporediti pripadnike (praviloma tiste, ki imajo določene zdravstvene omejitve in ne morejo opravljati vojaške službe oziroma formacijske dolžnosti, na katero so razporejeni) in opredeliti opis dela in nalog za pripadnike, ki jih bodo opravljali $\mathrm{v}$ VK.

Po oceni delovne skupine pilotskega projekta tak način organiziranja VK pomeni bistveno zahtevnejši način zagotavljanja kadra in manjšo transparentnost za organizacijo dela. V tem primeru bi šlo samo za razširitev opisa dela in nalog, druge pravice (osnovna plača, čin, dodatki) pa pripadnik zadrži iz formacijske dolžnosti, 
na katero je razporejen. Tak način organizacije bi negativno vplival na kakovost dela v VK.

\subsection{Izvajanje dejavnosti}

V okviru pilotskega projekta smo v VK začeli izvajati gostinsko dejavnost. Ta se izvaja znotraj lastne dejavnosti in na isti ali višji ravni, kot jo zagotavljajo zunanji izvajalci po drugih vojašnicah in objektih SV. Tak model izvajanja dejavnosti bi lahko bil vzorčni primer za izvajanje drugih dejavnosti.

Ena izmed lastnih dejavnosti bi lahko bila prodaja blaga. V okviru prodaje blaga bi pripadnikom ponujali nakup:

- kovinske galanterije (čini, našitki, napisi, kovinske ploščice z napisom),

- spominkov,

- različnih izdelkov neformacijske opreme (nahrbtniki, majice, kape, nogavice itn.).

V okviru delovanja VK bi lahko imeli tudi storitveni servis, ki bi izvajal:

- manjša obrtniška dela,

- pranje perila,

- manjša šiviljska popravila,

- frizerske storitve itn.

\subsection{Izvajanje programov v vojašničnih klubih}

Z VK bo doseženo boljše vzdušje med pripadniki SV in njihovimi družinskimi člani. V VK se bodo izvajali različni programi:

- strokovni programi (programi priprav na MOM in po vrnitvi iz MOM, programi psihološke podpore, programi socialnovarstvene pomoči),

- prostočasne aktivnosti (počitniške aktivnosti, tematski vikendi, likovne delavnice),

- športne dejavnosti (športni dnevi, pohodi, fitnes),

- drugi programi (sejmi, druženja, obveščanje).

Te programe bi ponudili:

- pripadnikom SV in njihovim družinskim članom,

- upokojenim pripadnikom SV,

- članom sorodnih organizacij veteranske organizacije ter drugih zvez in društev).

Programi za pripadnike SV in njihove družinske člane se izvajajo v pristojnosti OCSP. Programi upokojenih pripadnikov so v pristojnosti Direktorata za obrambne zadeve, Sektorja za vojaške zadeve (DOZ/SVZ). Preostali programi civilnih zvez in društev se izvajajo na podlagi sporazumov in načela recipročnosti v pristojnosti civilno-vojaškega sodelovanja (CVS).

V nadaljnjem procesu razvoja VK bi lahko postopoma vključevali prostovoljce, torej družinske člane, upokojene pripadnike ter pripadnike organizacij, zvez in društev, za izvajanje različnih aktivnosti. 


\section{PREGLED IZVAJANJA DEJAVNOSTI IN PROGRAMOV V ZDA}

\subsection{Združene države Amerike}

Pri predstavitvi enega izmed modelov, ki se uporablja v Ameriški vojski, lahko vidimo, kako oni izvajajo dejavnosti, s katerimi zagotavljajo ekonomske učinke za pripadnike oboroženih sil in njihove družinske člane. Ena izmed teh je AAFES (Army \& Air Force Exchange Service).

\subsubsection{Ameriška vojska \& Letalske sile - storitveni servis (Army \& Air Force Exchange Service)}

AAFES (Army \& Air Force Exchange Service (Exchange)) je agencija ameriškega ministrstva za obrambo, ki deluje že 120 let. Ves ta čas je njihovo poslanstvo podpirati pripadnike oboroženih sil med izvajanjem vojaških operacij, humanitarnih misij in drugih nalog po svetu in doma. Vodstvo agencije je v Dallasu v zvezni državi Texas (https://en.wikipedia.org/wiki/Army_and_Air_Force_Exchange_Service, 30. 8. 2015).

Agencija AAFES je zasnovana za zagotavljanje dobrin in storitev, ki bi jih pripadnik oboroženih sil hotel ali potreboval. Dobrine in storitve so oproščene davka, pogosto pa se zagotavljajo tudi visoki popusti pri nabavnih cenah. Ponudba obsega uniformo, taktično opremo, športno opremo, zdravila, vitamine, elektroniko, pohištvo in drugo. Storitev je na voljo 12,8 milijona uporabnikom v 50 zveznih državah in v več kot 30 državah po svetu. Leta 2013 je promet dosegel 8,3 milijarde USD in tako ustvaril 332 milijonov USD dobička. Tretjina dobička je ponovno naložena v operacije, preostali del (208 milijonov USD) pa v programe celostne skrbi za pripadnike ameriške vojske v okviru ameriškega ministrstva za obrambo. Programe izvaja organizacija AUSA.

Agencija obsega približno 2448 objektov, kar vključuje trgovine, butike in 1418 restavracij, kot so Taco Bell, Burger King and Starbucks, skozi katere izvaja dejavnosti in storitve. Poleg navedenega ima agencija še 3330 koncesijskih razmerij (http://www.aafes.com/about-exchange/history-mission/, 30. 8. 2015).

Slogan agencije je: Mi gremo tja, kamor greste vi (angl.: we go where you go).

Agencija AAFES ponuja storitve in podporo tudi družinskim članom pripadnikov ter enotam, ki se vračajo iz vojaških operacij po svetu.

Partnerstvo s programi celostne skrbi za pripadnike ameriške vojske v okviru ameriškega ministrstva za obrambo odraža lojalnost in predanost do pripadnikov oboroženih sil, ki presega ekonomske interese.

Prisotni so v 70 vojaških bazah s storitvenimi centri. Od tega jih je 53 lociranih $\mathrm{v}$ glavnih poveljstvih. 


\subsubsection{Struktura agencije Ameriška vojska in letalske sile - storitveni servis}

V agenciji AAFES je zaposlenih več kot 40.662 ljudi, od tega jih je 24 odstotkov družinskih članov pripadnikov OS in 2 odstotka aktivnih pripadnikov OS, ki delo opravljajo zunaj svojega rednega delovnega časa. Pri zaposlitvi imajo prednost nekdanji pripadniki oboroženih sil.

Vodstvo agencije AAFES je sestavljeno iz direktoratov. Nekatere izmed njih vodi vojaško osebje, nekatere pa civilni strokovnjaki (http://www.aafes.com/aboutexchange/our-organization/, 30. 8. 2015).

\subsection{Zveza ameriških oboroženih sil}

Skozi agencijo AAFES se finančno podpirajo različne zveze, katerih poslanstvo je dvig CSP v Ameriški vojski. Ena takih zvez je zveza ameriških oboroženih sil (AUSA), ki od leta 1950 deluje v podpori vseh vidikov nacionalne varnosti, pri čemer je izpostavljen interes oboroženih sil in njenih pripadnikov.

AUSA je zasebna, neprofitna izobraževalna organizacija, ki podpira stalno in rezervno sestavo oboroženih sil, nacionalno gardo, civilno osebje, upokojence, vladne uslužbence, ranjence, veterane in družinske člane vseh naštetih. AUSA ponuja več profesionalnih razvojnih priložnosti z organizacijo dogodkov na lokalni in nacionalni ravni.

AUSA zastopa vsakega pripadnika oboroženih sil z:

- zastopanjem vseh komponent ameriške vojske,

- spodbujanjem javne podpore vojaški vlogi v sistemu nacionalne varnosti,

- izvajanjem strokovnih izobraževalnih in informacijskih programov.

Vrednote, ki jih zagovarja AUSA, so odličnost, inovativnost, profesionalizem, odprtost, integriteta in odgovornost.

Po vsem svetu ima AUSA tudi 120 skupin, ki jih tvorijo prostovoljci. Skupine zagotavljajo možnosti za rekreacijo in izobraževanje pripadnikom OS in njihovim družinskim članom. AUSA in njene skupine so v preteklosti razdelile več kot 2 milijona USD za šolnine ter podporo vojaških in družinskih programov. Poslanstvo skupin je podpora družinskim članom v lokalni skupnosti za čas, ko so ti ločeni od svojih pripadnikov OS.

AUSA ponuja programe za podčastnike in vojake, upokojence in veterane, družinske člane pripadnikov OS, knjižnične programe, rezervno sestavo OS (http://www.ausa. org/Pages/default.aspx, 30. 8. 2015). 
Sklep Z vzpostavitvijo VK bi lahko izboljšali celostno skrb pripadnikov SV in njihovih družinskih članov.

Z izvajanjem dejavnosti v okviru VK lahko dosežemo ekonomske učinke. Z ekonomskimi učinki bi lahko podprli razvoj in izvajanje različnih novih programov za doseganje socialnih učinkov.

Skozi delovanje VK bi ustvarili tudi stičišče, ki bi omogočalo vez med različnimi organizacijami, zvezami in društvi.

Izbrana različica delovanja (lastna dejavnost) VK se je v okviru pilotskega projekta pokazala kot smotrna in učinkovita.

Delovanje VK bi zagotavljali s svojim kadrom. Tako se odpira priložnost za reševanje statusa pripadnikov SV, ki zaradi različnih omejitev (vojaki po 45. letu starosti, delovni invalidi, zakonske omejitve) niso zmožni začasno ali trajno opravljati vojaške službe.

Glede na nastale ekonomske in socialne razmere v SV je treba projekt VK nadaljevati. Delo pilotskega projekta VK se je v kratkem času preneslo iz analitične presoje v praktično delovanje in tako doseglo postavljene cilje.

Predlagam, da se sedanje izvajanje gostinske dejavnosti (»outsourcing«) v objektih SV postopoma zamenja s konceptom, kot ga ponuja pilotski projekt VK.

Pri širitvi izvajanja dejavnosti VK bo treba dopolniti predpis na tem področju (Navodilo o lastni dejavnosti MO RS) in tako omogočiti njihovo delovanje.

\section{Literatura}

1. Army \& Air Force Exchange Service; https://en.wikipedia.org/wiki/Army_and_Air_ Force Exchange Service, 30. 8. 2015.

2. Association of the United States Army; http://www.ausa.org/Pages/default.aspx, 30. 8. 2015.

3. Direktiva za razvoj in izvajanje celostne skrbi za pripadnike Slovenske vojske, GŠSV, št. 804-338/2009-1, z dne 16. 9. 2009.

4. Lipovec, F., Mesec, B., 2009. Vloga vojašničnih klubov pri zagotavljanju celostne skrbi za pripadnike SV. Specialistično delo. Maribor: Univerza v Mariboru.

5. Navodilo o lastni dejavnosti v Ministrstvu za obrambo, št. 017-04-7/2003-4, z dne 24. 2. 2003.

6. Pravila služb v SV (Uradni list RS, št. 84/2009).

7. SOP o načrtovanju programov celostne skrbi v enotah in poveljstvih SV in poročanje o realizaciji (SOP št. 05-0007, GŠSV št. 804-337/2009-1 z dne 10. 9. 2009).

8. Exchange. Our organization; http://www.aafes.com/about-exchange/our-organization/, 30. 8. 2015.

9. Štemberger, D., 2007. Izvajanje celostne skrbi za pripadnike slovenske vojske. Diplomsko delo magistrskega študija. Celje: Fakulteta za logistiko, str. 17.

10. Tepeh, A., 2011. Socialnovarstvena oskrba in družbena odgovornost v SV. Magistrska naloga. Koper: Fakulteta za management, str. 38.

11. Veselič, Z., 2009. Prilagoditev vojaške infrastrukture poklicni vojski s poudarkom na izvajanju programov celostne skrbi za pripadnike SV. Magistrska naloga. Celje: Fakulteta za logistiko, str. 81).

12. Vojaška doktrina (PDRIU 2006).

13. Zakon o službi v SV, ZSSloV (Uradni list RS, št. 68/2007). 